\title{
The High Priest in Chronicles \\ and in the Priestly Traditions of the Pentateuch
}

\section{Introduction}

The high priest in Chronicles has not been the subject of much research. The main publications on the topic consist of a chapter in Deborah Rooke's 2000 monograph, ${ }^{1}$ as well as an article by Steven J. Schweitzer from $2003 .{ }^{2}$ Even studies devoted to the cult and the temple in Chronicles often pay minimal attention to the high priest, and sometimes even no attention at all. Furthermore, while the connections between descriptions of the cult in Chronicles and in the priestly traditions of the Pentateuch have often been addressed in the scholarly literature, the parallels and differences between the image of the high priest in these two corpuses do not appear to have been subjected to a detailed analysis. The following essay will focus on two related themes: (a) the characterization of the high priest in Chronicles, and (b) its relationship to the description of the high priest in the priestly traditions of the Pentateuch.

Like many other topics in Chronicles, one key issue has to do with understanding the selection involved in the mentionings of high priests. The genealogy of Levi in 1 Chronicles 5:27-6:66 includes a comprehensive list of the high priests following Aaron, from Eleazar to Jehosadaq (1 Chr 5:27-41). Yet the Chronicler's account of the Judean monarchy in 1 Chronicles 10 to 2 Chronicles 36 only includes selected references to some high priests, as the following table shows:

1 Deborah W. Rooke, Zadok's Heirs: The Role and Development of High Priesthood in Ancient Israel, OTM (Oxford: Oxford University Press, 2000), 184-218.

2 Steven J. Schweitzer, “The High Priest in Chronicles: An Anomaly in a Detailed Description of the Temple Cult," Biblica 84 (2003): 388-402.

Christophe Nihan, University of Münster 


\begin{tabular}{lll}
\hline High priest & King & Text in Chronicles \\
\hline Zadoq & David & 1 Chr 12:29; 15:11; 16:39-40; 18:16; 24:3-6; 24:31; 27:17; \\
& & $29: 22$ \\
Amariah & Jehoshaphat & 2 Chr 19:11 \\
Jehoiada & Joash & 2 Chr 22:10-24:16 \\
Azariah (I) & Uzziah & 2 Chr 26:16-21 \\
Azariah (II) & Hezekiah & 2 Chr 31:10 \\
Hilkiah & Josiah & 2 Chr 34:8-28; 35:8 \\
\hline
\end{tabular}

It is probable that this difference is due to the fact that the high priestly genealogy in 1 Chronicles 5:27-41 was not part of the Chronicler's main composition but was added later, as it has often been suggested. ${ }^{3}$ Yet even so, it remains significant that the addition of the genealogy did not lead to any sort of systematic referencing of the high priests in the Chronicler's account. Instead, within 1 Chronicles 10 to 2 Chronicles 36 references to the high priest of Jerusalem remain highly selective, as the Table above exemplifies. It is not easy, at first sight, to understand the logic underlying this selection, if there is any. Assuming a traditional view of the relationship between Chronicles and Kings, ${ }^{4}$ it is likely that the Chronicler's references to the high priest are influenced by the reuse of materials from Kings, where a similar figure - the chief-priest of Jerusalem - is already mentioned. Yet this hardly accounts for all the references to the high priest in Chronicles, since comparison with Kings shows that Chronicles can either omit mentionings of the high priest or introduce new mentionings that have no parallels in Kings. Thus, for example, Chronicles ignores all mentionings of Zadok in connection with Solomon, ${ }^{5}$ with the result that in Chronicles Zadok is almost exclusively associated

3 See, e. g., Thomas Willi, Die Chronik als Auslegung, FRLANT 106 (Göttingen: Vandenhoeck \& Ruprecht, 1972), 214; and with more details Magnar Kartveit, Motive und Schichten der Landtheologie in 1 Chronik 1-9, ConBOT 28 (Stockholm: Almqvist \& Wiksell, 1989), 77-87. In this view, the genealogy in $1 \mathrm{Chr}$ 5:27-41 is a later addition within the Levitical genealogies, expanding upon the shorter list in $1 \mathrm{Chr}$ 6:38-41. Alternatively, other scholars consider that the list in $1 \mathrm{Chr}$ 5:27-41 is more likely to be chronologically prior; see, especially, Gary Knoppers, 1 Chronicles 1-9: A New Translation with Introduction and Commentary, AB 12 (New York et al.: Doubleday, 2003), 407-10, with additional references.

4 Specifically, I am assuming that the authors of Chronicles knew a composition comparable to Samuel and Kings, but which was still transmitted in a Hebrew form distinct from the MT of these two books. For further details, see my discussion in Christophe Nihan, "Textual Fluidity and Rewriting in Parallel Traditions. The Case of Samuel and Chronicles," JAJ 4 (2013): 186-209. 5 Cf. 1 Kgs 1:8, 26, 32, 34, 38, 39, 44, 45; 2:35; 4:2, 4. In Chronicles, the only context where Solomon and Zadoq are mentioned together is in $1 \mathrm{Chr} 29: 22$, which relates Solomon's appointment as David's successor. Incidentally, it is also the last notice mentioning Zadoq in the context of 
with David's reign. Conversely, Chronicles introduces an account about the high priest Azariah under the reign of king Uzziah (2 Chr 26:16-21), of which the parallel account in Kings knows nothing. In short, the mentioning of high priests in Chronicles cannot be simply explained by comparison with the evidence in Kings. Rather, in order to understand this, we need to take into account the way in which high priests are characterized in Chronicles. The following discussion will seek to identify some major trends in this characterization.

\section{The high priest and the sanctuary in Chronicles}

\subsection{The high priest and the rituals performed inside the sanctuary}

Except in the case of Jehoiada (2 Chr 22:10-24:16), who deserves a specific discussion (see below $\S 3$ ), most of the references to the high priest in Chronicles associate him closely to the sanctuary and the rituals performed there. In particular, various passages mention the high priest in contexts where sacrifices are performed. This view is already introduced in 1 Chronicles 6:34, a passage which is part of the genealogies and lists comprising 1 Chronicles 1-9.

1 Chronicles 6:34

ואהרן ובניו מקטירים על מזבח העולה ועל מזבח הקטרת לכל מלאכת קדש הקדשים ולכפר על ישראל ככל אשר צוה משה עבד האלהים: Aaron and his sons burnt (offerings) on the altar of burnt offering and on the altar of incense, (to perform) all the work of the most holy place, to effect kippēr (removal) for Israel, according to all what Moses the servant of the deity had commanded.

This verse is aptly located at the junction between the genealogies of the Levitical clans (v. 1-33) and the subsequent genealogy of the Aaronite line (v. 35-38). ${ }^{6}$ The description of Aaronite duties focuses on the offering of burnt offerings and

David's and Solomon's reigns. Of course, this has to do with the fact that Chronicles omits Kings' account of David's succession in 1 Kgs 1-2, where most of the references to Zadoq are found. Even so, however, it remains striking that Chronicles never mentions Zadoq in connection with Solomon's reign after the notice in $1 \mathrm{Chr}$ 29:22.

6 For more details on the location of $1 \mathrm{Chr} 6: 34$ and its significance, see, e. g., Sara Japhet, I \& II Chronicles. A Commentary, OTL (Louisville: Westminster John Knox, 1993), 156; and more recently Lars Maskow, Tora in der Chronik: Studien zur Rezeption des Pentateuchs in den Chronikbüchern, FRLANT 274 (Göttingen: Vandenhoeck \& Ruprecht, 2019), 281-2. 
incense on the corresponding altars, which is summarized with the expression "לכל מלאכת קדש הקדשים mention of the "altar of incense" refers to the practice prescribed in Exodus 30:7-8, where Aaron is instructed to offer incense every morning and evening on this altar located inside the outer-sanctum. ${ }^{8}$ This is confirmed by the fact that the end of the verse explicitly refers to the Mosaic legislation, including the priestly ritual instructions (ככל אשר צוה משה עבד האלהים). While Exodus 30 exclusively mentions Aaron, the high priest, in this context other passages indicate that the high priest could be accompanied by other Aaronite priests when he performed rituals inside the outer-sanctum. ${ }^{9}$ Presumably, this is what 1 Chronicles 6:34 has in view when it states that this ritual was performed by "Aaron and his sons." The reference to the altar of burnt offering, for its part, may include in principle all the sacrifices offered by the priests on behalf of Israel. However, the parallel with the altar of incense suggests that 1 Chronicles 6:34 may well have in view the daily ritual prescribed in Exodus 29:38-42 (see further Num 28:3-8), according to which Aaron and his sons must offer a whole burnt offering and accompanying grain offerings every morning and evening in the courtyard of the temple. Finally, the reference to the priests effecting the "removal" (of impurities, sins, etc.) from the community in the second half of the verse (ולכפר על ישראל) takes up a notion already present in the priestly traditions of the Pentateuch, where priests are described as performing kippēr (removal) by means of sacrifices. ${ }^{10}$ In short, 1 Chronicles 6:34 provides a short but essential description of priestly duties, which claims a significant degree of continuity with the Mosaic legislation. The

7 The lamed in לכל must probably be construed as expressing finality (thus, e.g., Thomas Willi, Chronik [1 Chr 1,1-10,14], BKAT XXIV/1 [Neukirchen-Vluyn: Neukirchener Verlag, 2009], 230). קדש While some scholars (e.g., Knoppers, 1 Chronicles 1-9, 425) opt to translate the phrase to mean "Holy of Holies," the formulation of this verse implies that its description refers to more than the rituals performed inside the inner-sanctum specifically. Therefore, it is arguably preferable to understand this phrase in a non-technical sense, as denoting the entirety of the temple compound. This usage of the phrase קדש הקדשים to denote the whole sanctuary is admittedly infrequent. It could be a case of metonymy, in which the sanctuary is designated through its most holy parts.

8 On this passage, and the offering of incense as a high priestly prerogative, see, e.g., the discussion by Menahem Haran, Temples and Temple-Service in Ancient Israel (Oxford: Clarendon, 1978), 208.

9 See, especially, Exod 27:21 concerning the daily disposal of the oil for the luminary. This is also suggested by Exod 31:20, which mentions both Aaron and his sons going inside the tent of meeting.

10 For this interpretation, see, e. g., Willi, Chronik 1,1-10,14, 230. For a recent restatement about the meaning of kipper in this context, see the helpful discussion by Marskow, Tora, 282-3. 
duties and prerogatives of the Aaronite priests are primarily defined in terms of the sacrifices they perform, and especially the rituals comprising the daily offering of burnt offerings and incense (Exod 29:38-42 and 30:7-8 respectively). Both rituals are placed under the authority of the high priest, but 1 Chronicles 6:34 emphasizes these rituals as a collaborative performance involving all Aaronite priests ("Aaron and his sons") rather than the sole high priest.

A very similar view is found a little later in the Chronicler's account, namely, in 1 Chronicles 16:39-40. ${ }^{11}$ David, after bringing the Ark to Jerusalem, appoints Zadoq (who had been only briefly mentioned until now in the account, $1 \mathrm{Chr}$ 12:29 and 15:11) and "his brothers the priests" to watch over the tabernacle which, at this point of the narrative, is staying in Gibeon according to Chronicles (see further 2 Chr 1:3-6; and for the reference to Gibeon, 1 Kgs 3:4). ${ }^{12}$ Zadoq and the other priests are then appointed with the following task:

1 Chronicles 16:39-40

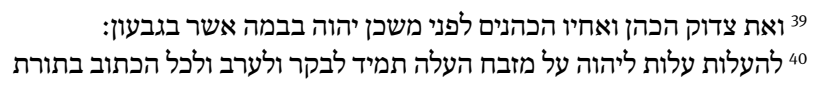

יהוה אשר צוה על ישראל:

${ }^{39}$ Zadok the priest and his brothers the priests were before Yhwh's dwelling in the high place at Gibeon ${ }^{40}$ to sacrifice burnt offerings to Yhwh upon the altar, the regular morning and evening burnt offering, according to all that is written in the Torah of Yhwh, which he prescribed to Israel. ${ }^{13}$

As in 1 Chronicles 6:34, the reference to the Mosaic legislation is explicit, ${ }^{14}$ and the focus of priestly ritual activity is on the daily burnt offering (Exod 29:38-42; Num 28:3-8). The syntax of verse 40a is somewhat ambiguous as regards the relationship between the proposition להעלות עלות ליהוה על מזבח and the following clause העלה תמיד לבקר ולערב, referring to the daily burnt offering. Presumably, this construction should be understood in the sense that the primary duty of

11 The continuity between the conception stated in $1 \mathrm{Chr}$ 16:39-40 with the earlier notice in $1 \mathrm{Chr}$ 6:34 has already been noted by various scholars. Cf., e. g., Japhet, Chronicles, 158.

12 On this issue, see my discussion in Christophe Nihan, "Cult Centralization and the Torah Traditions in Chronicles," in The Fall of Jerusalem and the Rise of the Torah, ed. Peter Dubovský, Dominik Markl \& Jean-Pierre Sonnet, FAT 107 (Tübingen: Mohr Siebeck, 2016), 253-88, here $267-75$.

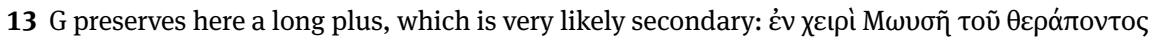

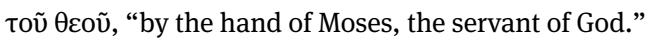

14 Despite the recent detailed argument by Maskow, Tora, 73-4, I remain unconvinced that it is necessary to understand the reference to Moses' Torah as including all of v. 39-40, rather than the performance of the daily burnt offering specifically, as most scholars tend to assume. For the present discussion, however, this point is not decisive. 
Zadoq and other priests is toward the continuous (תמיד) burnt offering presented twice every day to the deity, although this does not preclude the inclusion of other, more occasional burnt offerings presented in specific circumstances (see Lev 1). ${ }^{15}$ Whether the omission of the offering of incense, which is mentioned together with the daily burnt offerings in 1 Chronicles 6:34, is significant, is difficult to say. It may have to do with the fact that the tabernacle has not yet arrived in Jerusalem, and that the cult is still missing some key components, such as the Ark.

At any rate, this brief episode highlights two related concerns of the Chronicler, namely, (a) that David already instituted a regular sacrificial cult for the wilderness sanctuary at Gibeon, long before that sanctuary was brought to Jerusalem by his son, Solomon; and (b) that he did so by establishing Zadoq and his kinsmen as the only legitimate agents of this sacrificial cult. A parallel is thus established with the conception stated in 1 Chronicles 6:34: just like "Aaron and his sons" were appointed by Moses to perform the required rituals in the tabernacle at Mount Sinai, “Zadoq and his brothers” were appointed by David when the tabernacle was in Gibeon. In this conception, the sacrificial monopoly enjoyed by Zadoq and the priests under his command goes back to the reign of David himself, and predates the building of the temple under Solomon (see $2 \mathrm{Chr} 2-7$ ). However, neither David nor subsequent kings have any part in the rituals performed daily at the sanctuary. This point is further emphasized by the split in the description of two kinds of ritual performance at this point in the Chronicles narrative: while Zadoq and the other priests are left in Gibeon to perform the daily sacrifices, David is leading the procession bringing the Ark back to Jerusalem (1 Chr 15:25-16:36).

A further key text as regards the sacrificial monopoly of priests in general, and the high priest in particular, is found in the account of 2 Chronicles 26:16-21 narrating the origins of king Uzziah's skin disease. According to this account, Uzziah, in the course of his reign, became arrogant and committed a sacrilege (מעל) by entering the temple in order to offer incense on the altar of incense, despite the warning addressed by the high priest Azariah and the priests accompanying him. As a result, he was struck by Yhwh with a form of serious skin disease (צרעת), and forced to live secluded the rest of his days. ${ }^{16}$

15 According to $2 \mathrm{Chr} 1$, Solomon himself offered whole burnt offerings upon the altar in Gibeon; cf. 2 Chr 1:6.

16 Like most scholars, I regard the text as a literary unity. For a different view, see Zwickel, Räucherkult, 321-322; for a defense of the text's unity, see Steins, Chronik, 408-414. 


\begin{abstract}
2 Chronicles 26:16-21

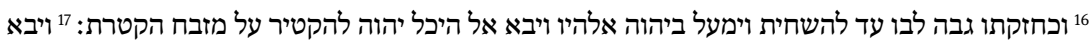

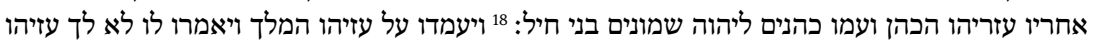

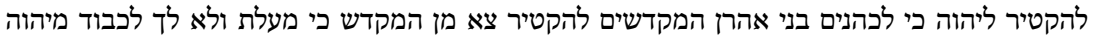

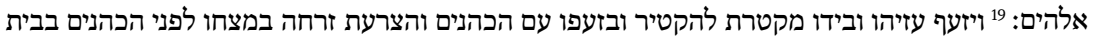

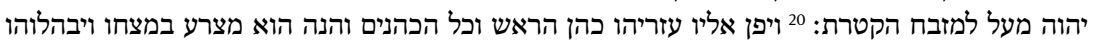

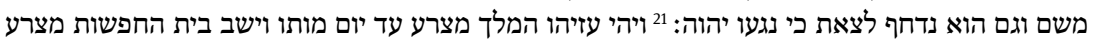

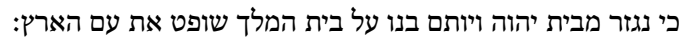

${ }^{16}$ But as he became strong, his heart grew proud, to the point of acting corruptly. ${ }^{17}$ He acted disloyally toward Yhwh his god, and went into the temple of Yhwh to burn incense on the altar of incense. ${ }^{17}$ Azariah the priest came after him, and with him eighty priests of Yhwh, men of valor. ${ }^{18}$ They stood by Uzziah the king and said to him: "It is not for you, Uzziah, to burn incense to Yhwh, but for the priests, sons of Aaron, who sanctify themselves to offer incense. Go out from the sanctuary, for you have acted disloyally, and there will be for you no honor from Yhwh Elohim!" ${ }^{19}$ Uzziah became furious: he had a censer in his hand, and when he became furious with the priests, a skin-disease (șāra'at) broke out on his forehead before the priests in the house of Yhwh, beside the altar of incense. ${ }^{20}$ Azariah the high priest and all the priests turned toward him, and behold: he had become a mẹsoră (one affected by skin disease) on his forehead. They hastened him out from there, and he himself hastened to go out, for Yhwh had struck him. ${ }^{21}$ Uzziah the king remained a mẹșoră until the day of

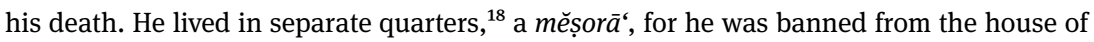
Yhwh. His son Jotham was in charge of the palace and ruled over the people of the land.
\end{abstract}

The motif of Uzziah's skin disease was taken from Kings' account; the parallel is all the more obvious since v. 21 (and the last two words of v. 20) are virtually identical with 2 Kings 15:5. Presumably, as several authors have surmised, the Chronicler was faced with the contradiction between Uzziah's length of reign (usually a sign of divine favor) and the tradition that he was severely struck by the deity. Consequently, he provided in a quasi-midrashic way an explanation for this tension. ${ }^{19}$ At the same time, and as is often the case in Chronicles, the story also serves to make an important point about the respective roles of priests and kings.

17 For this translation, and the interpretation of lěhašhît as an intransitive form in Chronicles, see Japhet, Chronicles, 885; Ralph W. Klein, 2 Chronicles: A Commentary, Hermeneia (Minneapolis: Fortress Press, 2012), 367.

18 With the majority of commentators, I follow the Qere hḥpšyt instead of the Ketib hḥpšwt, cf. also 2 Kgs 15:5.

19 E.g., Klein, 2 Chronicles, 377. Alternatively, some scholars have surmised that the Chronicler would have made use here of an older legend about Uzziah's leprosy; cf., e. g., Japhet, Chronicles, 877. While this view is possible, it is not likely, especially since the language and themes used in this account are typical of Chronicles. See also on this point the detailed discussion by Hugh G. M. Williamson, 1 and 2 Chronicles, NCBC (London: Marshall, Morgan \& Scott; Grand Rapids: Eerdmans, 1982), 338-9. 
While the main obligation of kings is toward the temple, which they are expected to finance and renovate, ${ }^{20}$ this gives them no right to perform rituals inside that temple. On the contrary, those rituals are the exclusive prerogative of the Aaronite priests, who are led by the high priest.

The nature of the sacrilege committed by Uzziah and its consequences are also remarkable and deserve a brief comment in the context of this essay. According to v. 16, Uzziah's intent is to offer incense on the altar of incense. As already mentioned above, in the priestly traditions of the Pentateuch the offering of incense on the altar located inside the outer-sanctum is a privilege of the high priest (Exod 30:7-8), although he can be accompanied by other priests (see above). Presumably, it is this kind of cooperative priestly performance supervised by the high priest that the account of Chronicles has in view when Azariah and the other priests declare that the offering of incense is a prerogative of "the priests who sanctify themselves”, and not just the high priest. This would also explain why Azariah is accompanied by no less than eighty priests described as בני חיל, a term that can be rendered as "men of valor" but also "men of standing" (scil. among the priests). ${ }^{21}$ In this way, the claim placed in the mouth of Azariah and the eighty priests is consistent with the priestly legislation of the Pentateuch; but whereas the priestly texts tend to emphasize the daily offering of incense as a prerogative of the high priest specifically, the account of 2 Chronicles 16 highlights instead the collective dimension of this ritual, which is performed by the Aaronite priesthood as a whole.

The interaction with the traditions of the Pentateuch, and especially with priestly texts, is not restricted to the description of Uzziah's transgression, however, but also extends to the king's punishment. As various authors have observed, the motif that Uzziah was struck while approaching Yhwh with a censer (מקטרת) is reminiscent of the story of Nadab and Abihu in Leviticus 10, as well as

20 See, e.g., David's donations to the temple in $1 \mathrm{Chr}$ 29:2-5. On the role of kings as patrons of the Jerusalem temple in Chronicles more generally, see also Jozef Tiňo, King and Temple in Chronicles. A Contextual Approach to Their Relations, FRLANT 234 (Göttingen: Vandenhoeck \& Ruprecht, 2010).

21 This interpretation highlighting the collective dimension of the performance of the daily burning of incense would remain correct even if the motif of the eighty priests following Azariah inside the sanctuary is secondary, as recently argued by Maskow, Tora, 527, following an earlier suggestion by Japhet, Chronicles, 877. However, Japhet's argument regarding the possibly secondary character of the eighty-priests-motif relates to the source used by the Chronicler, not the present account in $2 \mathrm{Chr}$ 26:16-21. Once this account is viewed as being entirely a literary creation by the Chronicler, as Maskow would accept, there is little evidence for this claim. At any rate, the point remains that the key statement voiced in v. 18 refers to "the priests, sons of Aaron" as responsible for the daily burning if incense, not just the high priest. 
of the 250 chieftains led by the Levite Korach in Numbers 16. In addition, the fact that Uzziah is sanctioned for his sacrilege by a severe skin disease (צרעת) is reminiscent of the story of Miriam in Numbers $12 .^{22}$ The parallel with Leviticus 10 and Numbers 16 is especially significant, since, as I have argued elsewhere, ${ }^{23}$ these two accounts form a system of sorts with the legislation on Yôm Kippur in Leviticus 16 , highlighting the point that the offering of incense on a censer before the deity is a privilege restricted to the high priest, when he enters the inner-sanctum once every year in order to purify it (see Lev 16:12-13). It seems likely, therefore, that the motif of Uzziah's being struck while he was holding a censer was introduced by the Chronicler in order to establish a link not only with the priestly legislation on the daily offering of incense in Exodus 30:1-10 but also with the grand ceremony of Leviticus 16. Finally, the fact that Uzziah's skin disease appears on his "forehead" (במצחו) may allude to the place of the golden plate worn by Aaron in Exodus 28:38. ${ }^{24}$ In this case, the allusion would strengthen the contrast between the high priest and the king, as well as the impossibility for the king to take over the high priest's role: Whereas Aaron's golden plate exemplifies both his holiness (since the plate is engraved with the inscription "holy to Yhwh") and his ability to "bear" the sin of the Israelites with regard to cultic transgressions (Exod 28:38), ${ }^{25}$ Uziah's skin-disease on his forehead publicly manifests his own fault, resulting in extreme uncleanness (cf. the treatment reserved to the měșorā in Lev 13-14).

If this reading is correct, it suggests that the account in 2 Chronicles 26:16-21 implies a fairly complex interaction with the priestly traditions of the Pentateuch - or at least more complex than it has sometimes been assumed. The Chronicler's choice to relate Uzziah's sacrilege with the offering of incense takes up and continues P's conception of incense as a key "marker" of the high priest's exclusive status and privilege (Exod 30:7-8). This textual strategy is further reinforced through the contrast built with the ceremony of Leviticus 16, and possibly the

22 For these parallels, see, especially, the recent and comprehensive discussion by Maskow, Tora, 524-42, esp. 525-6 and 529-32. Regarding the parallel with Num 12, Maskow notes, in particular, the phraseological connection between $2 \mathrm{Chr}$ 26:20a and Num 12:10b (Maskow, Tora, 531). 23 See Christophe Nihan, From Priestly Torah to Pentateuch: A Study in the Composition of Leviticus, FAT II 25 (Tübingen: Mohr Siebeck, 2007), 585-6.

24 As suggested, e.g., by Japhet, Chronicles, 887; see also the detailed discussion by Maskow, Tora, 532-4.

25 On the difficulties raised by the interpretation of this verse, and the reference to the "bearing of sin," see the discussion in Christophe Nihan \& Julia Rhyder, "Aaron's Vestments in Exodus 28 and Priestly Leadership," in Debating Authority, Concepts of Leadership in the Pentateuch and the Former Prophets, ed. Katharina Pyschny and Sarah Schulz, BZAW 507 (Berlin/Boston: De Gruyter, 2018), 45-67, here 59-61. 
allusion to the golden plate worn by Aaron on his forehead in Exodus 28. At the same time, the key speech placed in the mouth of Azariah and the other priests in v. 18 emphasizes the offering of incense as a collective priestly task, in a way that is unparalleled in $\mathrm{P}$.

One should note at this point that the same phenomenon can be observed in another key passage in Chronicles, 2 Chronicles 13:11, a verse which is part of king Abijah's speech to Jeroboam's army in 2 Chronicles 13:5-12. ${ }^{26}$ Abijah's speech, whose programmatic function in Chronicles has long been recognized, consists of two main parts. ${ }^{27}$ The first part (v. 5-7) states that Yhwh gave the "kingship over Israel” to David and his sons, "forever", as a "covenant of salt”, i. e., an everlasting covenant (see v. 5). The second part (v. 8-12) illustrates this claim by asserting that the only legitimate cult is located in the kingdom of Judah. Significantly enough, in Abijah's speech Judah's cultic legitimacy is demonstrated by the presence of Aaronite priests ("the sons of Aaron") performing the following tasks:

\begin{abstract}
2 Chronicles 13:11
ומקטרים ליהוה עלות בבקר בבקר ובערב בערב וקטרת סמים ומערכת לחם על השלחן הטהור ומנורת הזהב ונרתיה לבער בערב בערב כי שמרים ובערב אנחנו את משמרת וקטרת יהום ומרים אלהינו ואתם עזבתם אתו:

They offer to Yhwh burnt offerings every morning and every evening, as well as fragrant incense; (they set out) the stacks of bread ${ }^{28}$ upon the pure table, together with the golden lampstands and its lamps, so that they may burn every evening. For we are keeping the service of Yhwh, our god, whereas you have forsaken him (2 Chr 13:11).
\end{abstract}

As it has often been observed, all the elements in this description correspond to the four daily rituals prescribed in the priestly legislation: the daily burnt offering (Exod 29:38-42); the daily offering of incense (Exod 30:7-8); the disposal of the "bread of the presence" (לחם פנים) upon the golden table located inside the inner-sanctum (Exod 25:30; further Lev 24:5-9); and finally, the burning of the oil of the luminary (Exod 27:20-21). In other words, Judah's cultic legitimacy is expressed in 2 Chronicles 13:11 in terms of the performance of the daily rituals

26 On this account, see, especially, the study by Gary N. Knoppers, “'Battling against Yahweh’: Israel's War against Judah in 2 Chr. 13:2-20,” RB 100 (1993): 511-532.

27 The distinction between two main parts in Abijah's speech is generally acknowledged, although the exact division between these sections remains somewhat disputed. For a justification of the present division, see my discussion in Nihan, "Cult Centralization," 276 n. 86.

28 Hebrew $m^{\prime} r k t$ appears to be a variant form of the term ma ărākāh, which normally refers to a row. However, since the passage appears to refer to the ritual for the bread of presence, this rendering makes little sense here, as noted by various commentators. Compare, in particular, the detailed discussion by Jacob Milgrom, Leviticus 23-27: A New Translation with Introduction and Commentary (AB 3B; New York: Doubleday, 2001), 2096, on Lev 24:6, 7, where the term $m^{\prime} r k t$ is already used for the arrangement of the bread of presence. 
which, in the priestly texts, are all placed under the authority of the high priest. Yet in this passage the high priest is not specifically mentioned, and the Chronicler emphasizes instead the collective nature of the performance of these rituals by the "sons of Aaron" (2 Chr 13:10), i.e., the Aaronite priests. ${ }^{29}$

\subsection{Other high priestly roles in the administration of the sanctuary}

The passages discussed so far concern the role of the high priest in connection with the rituals performed inside the sanctuary. Other passages in Chronicles, however, indicate that his authority extends to other matters pertaining to the sanctuary, including administrative and legal ones. The account of 2 Chronicles 19:4-11 concerning king Jehoshaphat's appointment of judges in every town of Judah and the creation of a high court in Jerusalem (cf. Deut 17:8-13) ${ }^{30}$ concludes with the appointment of the high priest Amariah (2 Chr 19:11).

2 Chronicles 19:11a

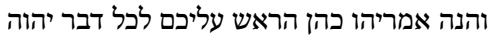

$$
\begin{aligned}
& \text { וזבדיהו בן ישמעאל הנגיד לבית יהודה לכל דבל דבר המלך ושרוה ושרים הלוים לפניכם }
\end{aligned}
$$

Amariah the chief priest will be over you in every matter concerning Yhwh, whereas Zebadiah the son of Ishmael, the leader of the house of Judah, will be over you in every matter concerning the king, and the Levites present with you shall be your officials.

The distinction between דבר יהוה, "the matter of Yhwh," and דבר המלך, "the matter of the king" is not entirely clear and has been the subject of some debate. While we must be careful not to project a modern, anachronistic distinction between "religious" and "secular" matters, which would have been unknown in Antiquity, ${ }^{31}$

29 The only alternative would be to understand the expression בני אהרן in 2 Chr 13:10 to refer to those descendants of Aaron who became high priests in Jerusalem specifically. However, such reading would be entirely inconsistent with the usage of this construct elsewhere in Chronicles, where it is always used to denote all the priests claiming descent from Aaron, not the high priest specifically. It also stands in tension with the use of בני אהרן in the previous verse (2 Chr 13:9), where this construct is clearly used in a broad, collective sense to denote priests collectively (note, in particular, the parallel in this verse with the Levites).

30 For a detailed analysis of the reception of Deut 17 in 2 Chr 19:4-11 (especially v. 8-11), see Sarah J.K. Pearce, The Words of Moses. Studies in the Reception of Deuteronomy in the Second Temple Period (TSAJ 152; Tübingen: Mohr Siebeck, 2013), 252-263; as well as Maskow, Tora, 163-182.

31 As rightly pointed out, e. g., by Steven L. McKenzie, 1-2 Chronicles, AOTC (Nashville: Abingdon Press, 2004), 294. 
דבר and the is something to be said for the view that the reference to דבר יהוה דבר has to do primarily with the legal and administrative matters concerning the temple and the palace respectively. ${ }^{32}$ If this interpretation is correct, the high priest Amariah is acknowledged as having authority over the Levites, the priests and the heads of the families who comprise the high court in Jerusalem (see 2 Chr 19:8) for all the judicial matters that pertain to the temple and its cult. Like Zebadiah, however, he remains subordinated to the king, who is responsible for his appointment. In fact, as Yigal Levin aptly points out, both men are best described as representatives of the king in the high court. ${ }^{33}$

A similar situation is reflected in subsequent passages of Chronicles. 2 Chronicles 23:18-19 describes Jehoiada assigning priests and Levites their duties in the temple. While this description concludes the narration of Joash's accession to the throne in 2 Chronicles 23, which gives a prominent place to Jehoiada (more on this below), the notice in v. 18-19 is consistent with the view already expressed in 2 Chronicles 19:11 according to which the high priest is responsible for the overall administration of the temple, and as such has authority (at least in principle) over the various priestly and Levitical classes. Additionally, another notice earlier in the same account, 2 Chronicles 23:8, also suggests that for the Chronicler the high priest was responsible to oversee the shifts of the Levitical groups active inside the temple. ${ }^{34}$ According to 2 Chronicles 31:10, under Hezekiah the high priest Azariah was in charge of managing the sacred donation, or contribution (תרומה) brought by the community to the temple. Further in the account, the same Azariah is described as נגיד בית האלהים, "leader of the house of the god" (2 Chr 31:13), a title which is reminiscent of Zebadiah's title as נגיד לבית יהודה, "leader of the house of Judah," in 2 Chronicles 19:11. ${ }^{35}$ Nonetheless, the account also implies that king Hezekiah has some degree of authority over the management of the temple, since it is he who orders that storerooms be prepared to gather the community's contribution (2 Chr 31:11). The supervision of the contributions stored in the temple is eventually placed under the joint authority of the king and the high priest (2 Chr 31:13). Finally, two passages in Chronicles, 2 Chronicles 24:11 and 34:9, describe the high priest being involved in the supervision of financial

32 Thus McKenzie, 1-2 Chronicles, 294, who speaks of a distinction between "cultic" and "non-cultic." In effect, this seems to be the majority view among scholars, compare also, e.g., Yigal Levin, The Chronicles of the Kings of Judah. 2 Chronicles 10-36: A New Translation and Commentary (London: Bloomsbury T\&T Clark, 2017), 132.

33 Levin, Chronicles, 132.

34 As pointed out, in particular, by Schweitzer, "High Priest," 398-9.

35 For a detailed justification of the translation of נגיד as "head" or "leader" in this context, see Levin, Chronicles, 126-8. 
matters in the context of the reconstruction of the temple. In 2 Chronicles 24:11 the money collected by the Levites is brought to "the scribe of the king and the official of the high priest” (סופר המלך ופקיד כהן הראש), presumably to be counted by them (cf. 2 Kgs 12:10); whereas in 2 Chronicles 34:9, the money is presented to the high priest Hilkiah alone. Both notices, however, are based on a previous notice in Kings (2 Kgs 12:10 and 22:4 respectively), so that it is difficult to derive substantial conclusions for Chronicles on the basis of these passages. However, there is some evidence that Chronicles slightly emphasizes the status of the high priest Jehoiada in the first account. Jehoiada is now provided with an official seconding him, like the king ( $2 \mathrm{Chr} 24: 11)^{36}$; and he is responsible, together with the king, for handing over the money to the workers appointed for the repairs of the temple (2 Chr 24:12). ${ }^{37}$

Overall, despite the selective nature of the references to the high priest in Chronicles and the absence of a comprehensive description of this figure and its main duties and prerogatives, a fairly coherent picture nonetheless emerges. Various passages describe the high priest as enjoying leadership over the sanctuary not only in ritual matters, but in legal, administrative and financial matters as well; and this conception is somewhat exemplified by the designation of the high priest Azariah in 2 Chronicles 31:13 as נגיד בית האלהים. At the same time, some passages suggest that the king preserves a substantial degree of control over the temple, as far as legal and administrative matters are concerned. In particular, the appointment of Amariah by Jehoshaphat in the notice of 2 Chronicles 19:11 indicates that the high priest receives from the king his authority in judicial matters pertaining to the temple and the cult. Likewise, the account in 2 Chronicles 31:1113 implies that king Hezekiah could legitimately involve himself in the management of the temple, at least in specific circumstances like the ones described in 2 Chronicles 31. Finally, Chronicles does not revise Kings' tradition according to which the repairs of the temple in Jerusalem were initiated by the king, not the high priest (2 Chr 24:4-14 // 2 Kgs 12:4-16; 2 Chr 34:8-14a // 2 Kgs 22:3-7). Nonetheless, Chronicles does highlight the role of Jehoiadah to some extent by explicitly presenting him and the king in 2 Chronicles 24:11 as financing together the build-

36 As Klein, 2 Chronicles, 342, aptly comments: "One suspects that the Chronicler invented this official [...] because he thought that the chief priest should not be involved in something as menial or mundane as counting money" (cf. 2 Kgs 12:10).

37 As pointed out by several scholars; compare, e. g., Klein, 2 Chronicles, 342; Levin, Chronicles, 207. However, it may have been the Chronicler's understanding that Jehoiada was included in the third person masculine plural used in the corresponding passage, 2 Kgs 12:11, especially since this priest was mentioned immediately before (v. 10). At any rate, Chronicles makes the involvement of Jehoiada more explicit at this point of the account. 
ers appointed for the repairs of the sanctuary. All in all, one gets the impression that Chronicles aims toward a balance of sorts between royal and high priestly supervision of the sanctuary. The king, as the patron and financial sponsor of the temple, retains a substantial degree of authority over its management; but he cannot do without the collaboration of the high priest, who is in effect the main administrator of the temple. This conclusion is consistent with the view, already expressed by some scholars, that those passages describing the king and the high priest working together for the benefit of the temple, such as 2 Chronicles 24:11-14 or 31:9-13, represent something of an ideal scenario in Chronicles. ${ }^{38}$ In some ways, this can be seen as a compromise between the situation prevailing in monarchic times, where the temple of Jerusalem was presumably much more strictly controlled by the kings of Judah, ${ }^{39}$ and the priestly ideal of a temple fully controlled by the high priest and his family. It may also reflect the situation at the time of the Chronicler, since some traditions suggest that the management of the temple was disputed between the high priest and the representative of the foreign ruler in the Late Persian and Early Hellenistic periods. ${ }^{40}$ In this case, Chronicles' description may be intended to promote collaboration rather than conflict between the high priest and the local ruler with regard to temple management.

Matters are quite distinct with regard to the performance of rituals inside the temple. In this case, Chronicles acknowledges more fully the authority of the high

38 E.g., Klein, 2 Chronicles, 451, in the case of 2 Chr 31:9-10: "This is the Chronicler's understanding of an ideal sharing of power."

39 The book of Kings, in particular, consistently shows the chief-priest of Jerusalem subordinated to the Judean kings. However, one may date these texts, there is little doubt that this motif reflects the situation effectively prevailing under the monarchy. See on this the detailed discussion by Deborah W. Rooke, Zadok's Heirs. The Role and Development of the High Priesthood in Ancient Israel (Oxford: Oxford University Press, 2000), 72-9, for the traditions about the period from the divided monarchy to the fall of Jerusalem; and cf. also James C. VanderKam, "Joshua the High Priest and the Interpretation of Zechariah 3,” CBQ 53 (1991): 553-70, here 559.

40 This is suggested, in particular, by the tradition reported by Josephus in Ant. 11, 297-301 regarding the conflict between the Persian governor Bagoses (Bagohi) and the high priest Johannes (Yohanan). With various scholars, I consider it likely that Josephus has used a source for this account, which may go back to the Late Persian or Early Hellenistic period. See recently Rainer Albertz, "The Controversy between Judean Versus Israelite Identity and the Persian Government: A New Interpretation of the Bagoses Story (Jewish Antiquities XI.297-301)," in Judah and the Judeans in the Achaemenid Period: Negotiating Identity in an International Context, ed. Oded Lipschits et al. (Winona Lake: Eisenbrauns, 2011), 483-504, although I would disagree with some aspects of the interpretation that he offers. Another piece of evidence for the growing interest of the Persian governor for some degree of control over the temple of Jerusalem is provided by the account of Neh 13:4-9, which should likewise be dated to the Late Persian or Early Hellenistic period. 
priest. Nonetheless, the range of ritual activities with which the high priest is effectively associated is limited. Specifically, high priestly ritual performance appears to be consistently associated, in various passages of Chronicles, with the offering of sacrifices, and especially the daily burnt offering and the burning of incense. This view is already introduced in connection with Aaron in the notice of 1 Chronicles 6:34, which mentions the daily sacrifice of burnt offerings and incense by Aaron and his sons in the tabernacle. It is continued in 1 Chronicles 16:39-40, which refers to the daily burnt offering presented by Zadoq and the other priests in Gibeon; and it somehow culminates in the account of Uzziah's cultic transgression in 2 Chronicles 26:16-21, which establishes the exclusive privilege of the Aaronite priests led by Azariah to burn incense on the altar of incense (v. 18). While this point has not always been noted by scholars, the way in which Chronicles defines the ritual expertise and authority of the high priest in terms of the daily rituals performed inside the sanctuary, and especially the daily burnt offering and the burning of incense, is striking. It suggests that for the Chronicler much of the prestige and status of the high priest and his family were actually mediated by the continued performance of those daily rituals. Presumably, this may be the reason why the account of Jehoiada - certainly one of the most successful high priests in Chronicles - concludes with the mention that "burnt offerings were offered in the temple of Yhwh continuously during all the days of Jehoiada” (תיהיו מעלים עלות בבית יהוה תמיד כל ימי יהוידע 2 Chr 24:14b). Apparently, for the Chronicler, the capacity of the high priest to maintain the daily burnt offering (and presumably other daily rituals as well) is a key marker of the success of his high priesthood. This conception may well reflect the situation effectively applying at the time of the Chronicler, in the sense that the high priestly family presumably exercised a monopoly of sorts over the regular sacrifices offered at the temple in Jerusalem and derived a substantial portion of its economic and political status from this monopoly.

Additionally, this view is also consistent with the priestly ritual legislation, which likewise defines high priestly authority in terms of the performance of the daily rituals. This conformity is actually highlighted in Chronicles, which explicitly refers to the Mosaic legislation in connection with the daily rituals performed by the high priest (1 Chr 6:34; 16:39-40). However, the priestly texts have several other ways to express the ritual authority and even monopoly of the high priest within the sanctuary, such as the description of his holy vestments (Exod 28); ${ }^{41}$ the ceremony of Yom Kippur (Lev 16); as well as specific laws pertaining to the high priest (Lev 21:10-15). None of this is mentioned in Chronicles, where high

41 See on this Nihan and Rhyder, "Aaron's Vestments," 45-67. 
priestly ritual monopoly is more exclusively defined through the daily rituals performed inside the sanctuary. Another difference with the priestly traditions concerns the collective dimension of the rituals associated with the high priest. While the priestly texts are not entirely consistent on this point (cf. Exod 29:38-42), they tend nonetheless to highlight high priestly agency in the performance of the daily rituals. In effect, some texts, like Exodus 30:7-8 (daily offering of incense) or Leviticus 24:1-4 (the oil of the luminary) only mention Aaron (the high priest) as the ritual agent. By contrast, Chronicles never ascribes the performance of daily rituals to the high priest alone, but always mentions other priests alongside him (see 1 Chr 6:34; 16:39-40). Moreover, texts like 2 Chronicles 13:11 or 26:18 even ascribe the performance of those same rituals to "the priests, sons of Aaron," rather than the high priest himself. This is not to say, of course, that Chronicles seeks to challenge high priestly authority in regard to the performance of daily rituals. Rather, the Chronicler's point in this description seems to be to emphasize the collective nature of high priestly authority: namely, the ritual monopoly enjoyed by the high priest inside the temple cannot be dissociated from the support of other priests.

\section{The high priest and communal leadership: the case of Jehoiada}

The discussion so far has concerned the description of the high priest in connection with the temple, its administration, and its rituals in Chronicles. We also need to ask, however, whether and to what extent Chronicles envisions a larger communal role for the high priest, alongside the king. The main piece of evidence for this is provided by the account of 2 Chronicles $22-24$ about king Joash and the high priest Jehoiada, which is also the most extensive account about a high priestly figure in Chronicles.

A key issue here has to do with the way in which the Chronicler's account in 2 Chronicles 22-24 rewrites its source in 2 Kings $11-12 .^{42}$ It should be clear that, as is often the case, the Chronicler's rewriting does not pursue one, but several

42 For a recent analysis of some key aspects of Chronicles' rewriting in $2 \mathrm{Chr} 22-24$, focusing on the account of Jehoiada's coup in 2 Chr 22:10-23:21, see Juha Pakkala, "Selective Transmission of the Past in Chronicles: Jehoiada's Rebellion in 2 Kings 11 and 2 Chronicles 22:10-23:21,” in Remembering and Forgetting in Early Second Temple Judah, ed. Ehud Ben Zvi and Christoph Levin (FAT 85; Tübingen: Mohr Siebeck, 2012), 239-256. 
aims simultaneously. In particular, Chronicles highlights the joint involvement of the community and the clergy in the reinstatement of Joash on the throne ${ }^{43}$; it gives to the Levites a central role in protecting the king and acting like bodyguards for him; ${ }^{44}$ and, most importantly, it makes explicit that the sanctity of the temple was preserved throughout the whole procedure. ${ }^{45}$ Additionally, one may ask whether, and to what extent, this rewriting also confers an extended role to the high priest Jehoiada. This possibility is rejected by Deborah W. Rooke in her monograph, ${ }^{46}$ but briefly mentioned by Schweitzer in his article on the high priest in Chronicles. ${ }^{47}$ On closer examination, there is indeed some evidence supporting the latter view.

(1) According to 2 Chronicles 22:11, Jehoshabeath, daughter of king Yoram, who is responsible for hiding Joash inside the temple and therefore protecting him from Athaliah (cf. 2 Kgs 11:2), was in fact the wife of Jehoiada. Despite some contrary views, ${ }^{48}$ it is unlikely that this information has any historical basis. ${ }^{49}$ It is more likely to have been introduced by the Chronicler. Presumably, as various scholars have surmised, the primary function of this motif is to explain

43 Compare $2 \mathrm{Chr}$ 23:1-11 with $2 \mathrm{Kgs}$ 11:4-12. In 2 Chr 23:2, Chronicles adds a notice according to which the "officers of the hundreds" (2 Chr 23:1, cf. 2 Kgs 11:4) went through Judah to gather "the Levites from all the towns of Judah and the heads of the families of Israel." In v. 3, the covenant in support of Joash is made with "all the assembly," not just the military officers as in Kings. In v. 5, Chronicles adds a reference to "all the people" standing in the courts of the temple. In v. 8 , the "officers of the hundreds" are replaced with "the Levites and all Judah." In v. 10, finally, Chronicles replaces the reference to "the guards" protecting Joash with "all the people." On this motif, see, e.g., the brief comments by Klein, 2 Chronicles, 331.

44 Compare 2 Chr 23:4-7 with 2 Kgs 11:4-8. According to Kings, the "Carites and the runners" are arranged into three groups; in Chronicles' version, it is now the Levites who are divided into three groups. The implications of this change are made clear in $2 \mathrm{Chr} 23: 7$ (cf. $2 \mathrm{Kgs} \mathrm{11:8),} \mathrm{where} \mathrm{it}$ is now the Levites who are tasked with the protection of the king.

45 In particular, Chronicles' account in 2 Chr 23:1-11 makes clear that only the Levites enter the temple during the coup (cf. $2 \mathrm{Chr} 23: 6$ ), whereas the rest of the community stands in the courts of the temple (cf. 2 Chr 23:5b). See on this, e. g., the comments by Levin, Chronicles, 195-196. Presumably, this is one of the reasons (albeit not the only one) for the replacement of the Carites with the Levites, as argued by Pakkala, "Selective Transmission," 247: “The change is understandable because the rebellion began in the temple, and it would certainly have disturbed the Chronicler to have foreign mercenaries enter an area where not even lay Judeans were allowed [...].”

46 Rooke, Zadok's Heirs, 208-210.

47 Schweitzer, "High Priest," 397-399.

48 E.g., Williamson, Chronicles, 314-315; Japhet, Chronicles, 828.

49 Compare, e. g., the recent discussions by Klein, 2 Chronicles, 322; Pakkala, "Selective Transmission," 245-246. 
the presence of Jehoshebat inside the temple. ${ }^{50}$ In addition, it also accounts for the connection between Jehoshabeath and Jehoiada, which is implied but never explained in the text of Kings. In any case, the effect produced by this addition is to move Jehoiada much closer to the royal house, since in Chronicles' version he has now married into the Davidic line. This is all the more striking because, as already pointed out by some scholars, ${ }^{51}$ Jehoiada's marriage with Jehoshabeath appears to stand in contradiction with the law of Leviticus 21, which requires that the high priest can only marry a virgin of his own "kin” (Lev 21:14).

(2) In 2 Chronicles 23:3, which substantially rewrites 2 Kings 11:4, the people gathered at the temple, presumably inside the courtyard (see $2 \mathrm{Chr} 23: 5$ ), makes an alliance with the king. This alliance is accompanied by the following statement from Jehoiada: הנה בן המלך ימלך כאשר דבר יהוה על בני דויד, "Look, the son of the king will be king, ${ }^{52}$ according to what Yhwh declared about the sons of David!"53 While this addition serves to highlight that Joash's reinstatement was a legitimate procedure rather than a coup, it also serves simultaneously to position the high priest Jehoiada as the first supporter of the Davidic line.

(3) The description of Joash's installation in 2 Kings 11:10-12 has been subtly but nonetheless significantly rewritten in 2 Chronicles 23:9-11 to the benefit of Jehoiada.

50 Thus most recently Pakkala, "Selective Transmission,” 246. Schweitzer, "High Priest,” 397, aptly observes that this would not account for the problem raised by the presence of Joash inside the temple. This objection is based on a correct observation, but it does not necessarily rule out the usual explanation. As pointed out by Pakkala, it would have been difficult for the Chronicler to omit entirely the motif of Joash being hidden inside the temple, "because many details in the ensuing story were dependent on his [Joash's] hiding place."

51 E.g., Schweitzer, "High Priest," 397.

52 This translation of the first half of Jehoiada's statement follows the Masoretic accents; compare also the Greek text $(\mathrm{G})$ of Chronicles.

53 This appears to refer to Chronicles' version of the promise to David, 2 Chr 17:12-14, which is repeated at several key passages in Chronicles' account of the Judean monarchy: $1 \mathrm{Chr} 22: 9-10$; 28:6-7; 2 Chr 13:5. See Klein, 2 Chronicles, 324. 


\begin{tabular}{|c|c|}
\hline 2 Chr 23:9-10 MT & 2 Kgs 11:10-11 MT \\
\hline 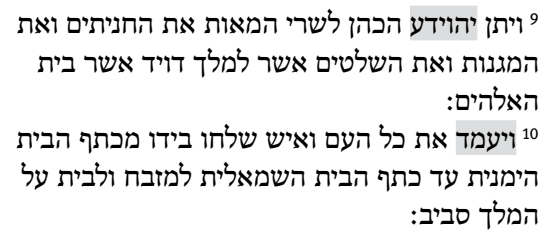 & 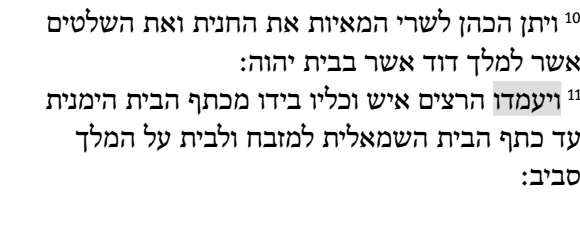 \\
\hline $\begin{array}{l}{ }^{9} \text { Jehoiada the priest gave to the officers of } \\
\text { the hundreds the spears, the shields and } \\
\text { the bow cases }{ }^{54} \text { (?) which belonged to king } \\
\text { David, and which were in the house of the } \\
\text { god. }\end{array}$ & $\begin{array}{l}{ }^{10} \text { The priest gave to the chiefs of hundreds the } \\
\text { spears and the bow cases which were for king } \\
\text { David, and which were in the house of Yhwh. }\end{array}$ \\
\hline $\begin{array}{l}{ }^{10} \text { He stationed all the people round, each } \\
\text { with a weapon in his hand, from the south } \\
\text { side of the house to the north side of the } \\
\text { house, around the altar and the house, } \\
\text { around the king. }\end{array}$ & $\begin{array}{l}{ }^{11} \text { The runners stood, each with his weapon in } \\
\text { his hand, from the left side of the house to the } \\
\text { right side of the house, around the altar and } \\
\text { the house, around the king. }\end{array}$ \\
\hline
\end{tabular}

In Chronicles' version, it is Jeohiada who is responsible for stationing the people in arms around the king, thereby highlighting his role in the whole procedure. Additionally, 2 Chronicles 23:9 adds the mention "Jehoiada" before הכהן, thus leaving no doubt that "the priest" responsible for providing weapons to the supporters of Joash is in effect Jehoiada.

The matter is more complex in the case the relationship between the next verse, 2 Chronicles 23:11 and 2 Kings 11:12. The MT version of 2 Kings 11:12 has the first two verbs in the singular (v. 12a $)$ ), then shifts to the plural. This suggests that Jehoiada is responsible for bringing Joash, for placing on him the diadem (נזר), and for giving to him the "testimony" (עדות), while the rest of the procedure is ascribed to the "officers of the hundreds" and the guards. In the main Greek versions of Kings, however, not just the first two verbs but all four verbs in v. 12a are in the singular, and therefore ascribed to Jehoiada. ${ }^{55}$

54 For this rendering of השלטים, see Klein, 1 Chronicles, 394 (at 1 Chr 18:7).

$55 \mathrm{G}^{\mathrm{L}}$ has the reverse order for the third and fourth verbs in the singular: "he anointed him and made him a king”. According to Steven L. McKenzie, 1 Kings 16 - 2 Kings 16 (IECOT; Stuttgart: Kohlhammer, 2019), 427, this reading is more logical and should be viewed as superior to $\mathrm{G}^{\mathrm{B}} \mathrm{s}$ reading, which agrees with MT and may represent a case of secondary alignment within the Greek tradition. While this is indeed possible, the fact that the sequence of verbs in $\mathrm{G}^{\mathrm{L}}$ is more logical is not necessarily an argument for the priority of this reading. It could likewise represent a case of a facilitating reading. For the present discussion, this point is not significant and can remain open. 


\begin{tabular}{|c|c|}
\hline 2 Kgs 11:12 MT & 2 Kgs 11:12 LXX (GB) \\
\hline 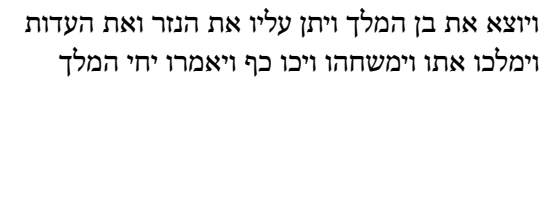 & 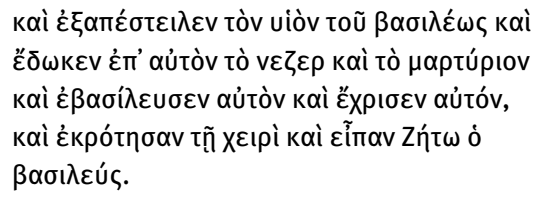 \\
\hline $\begin{array}{l}\text { He (Jehoiada) brought out the son of the } \\
\text { king, put on him the diadem and the } \\
\text { testimony }{ }^{56} \text {; they made him king and } \\
\text { anointed him, they clapped their hands } \\
\text { and said: "Long live the king!" }\end{array}$ & $\begin{array}{l}\text { He (Jehoiada) brought out the son of the king, } \\
\text { put on him the diadem and the testimony, } \\
\text { made him a king and anointed him; they } \\
\text { clapped their hands and said: "Long live the } \\
\text { king!" }\end{array}$ \\
\hline
\end{tabular}

The MT version of the corresponding passage in 2 Chronicles 23:11, for its part, has all the verbs in the plural. In this case, the subject is most likely Jehoiada and his sons, who are mentioned at the beginning of v. $11 \mathrm{~b} .{ }^{57}$ However, the Greek version of Chronicles preserves a different wording, according to which the first two verbs are in the singular, and therefore describe actions ascribed to Jehoiada alone, whereas the following verbs are ascribed to "Jehoiada and his sons."

\begin{tabular}{|c|c|}
\hline 2 Chr 23:11 MT & 2 Chr 23:11 LXX (GB) \\
\hline העדות וימליכו אתו או המלך ויתנו עליו אתו יהוידע הנזר ובניו ויאמרו & 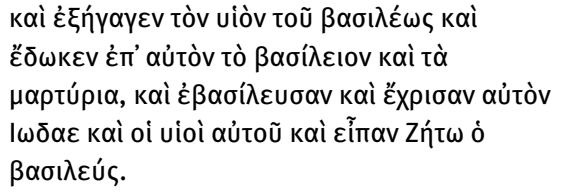 \\
\hline $\begin{array}{l}\text { Then Jehoiada and his sons brought out the } \\
\text { son of the king, placed on him the diadem } \\
\text { and the testimony; they made him king, } \\
\text { they anointed him and said: "Long live the } \\
\text { king!" }\end{array}$ & $\begin{array}{l}\text { Then he (Jeoiada) brought out the son of the } \\
\text { king, and gave him the kingdom and the testi- } \\
\text { mony. Jehoiada and his sons made him king, } \\
\text { they anointed him and said: "Long live the } \\
\text { king!" }\end{array}$ \\
\hline
\end{tabular}

56 For the problem raised by the term עדות in this context, see the recent and detailed discussion by McKenzie, 1 Kings 16 - 2 Kings 16, 439-440. McKenzie himself follows Wellhausen in emending נזר צעדות to denoting "bracelets" or "armbands", which is attested together with the term in 2 Sam 1:10.

57 The previous collective subjects in Chronicles' account are the "officers of the hundreds" mentioned in $2 \mathrm{Chr}$ 23:9 and the people mentioned in v. 10. It is unlikely that Chronicles would have ascribed the actions described in v. 11, especially the crowning of the king and his anointing, to these groups. It is more likely, therefore, that all the verbs in the plural are implicitly ascribed to the other collective mentioned in v. 11, namely, Jehoiada and his sons. 
Several scholars consider that the Greek version of 2 Chronicles 23:11 should be preferred, ${ }^{58}$ and this conclusion seems indeed likely. The Greek version effectively corresponds to 2 Kings 11:12 MT, except that the verbs in the plural are now effectively ascribed to "Jehoiada and his sons," rather than to the officers and the guards, as in Kings' version (see above). MT's version, for its part, could reflect a secondary attempt to harmonize the syntax of this verse by ascribing all the actions it narrates to the high priest Jehoiada and his sons. Even so, however, the difference merely concerns the extent of Jehoiada's personal involvement in the procedure described in 2 Chronicles 23:11. Both versions actually concur in placing this procedure under the high priest's authority, whether some actions are performed by Jehoiada alone (thus LXX, as in 2 Kgs 11:12 MT already), or Jehoiada is consistently assisted by other priests (thus MT). Either way, Chronicles now places the entirety of the ceremony establishing Joash as king over Judah under the responsibility of Jehoiada.

(4) In 2 Chronicles 23:16, the covenant concluded by Jehoiada after Athaliah's death contains a noticeable difference with the version of this covenant in Kings:

\begin{tabular}{|c|c|}
\hline 2 Kgs 11:17a MT & 2 Chr 23:16 MT \\
\hline העם להיות לעם ליהוה הברית בין יהוה ובין המלך ובין & לעם ליהוה: \\
\hline $\begin{array}{l}\text { Jehoiada concluded the covenant between } \\
\text { Yhwh, the king and the people, so that they } \\
\text { should be Yhwh's people. }\end{array}$ & $\begin{array}{l}\text { Jehoiada concluded a covenant between him- } \\
\text { self, all the people and the king, so that they } \\
\text { should be Yhwh's people. }\end{array}$ \\
\hline
\end{tabular}

Again, the variation in Chronicles is subtle but nonetheless substantial. Chronicles' reading, replacing בינו with presumably reflects an understanding that the high priest acts here as the representative of the deity. ${ }^{59}$ Even so, however, the effect produced is significant: in Chronicles' formulation, Yhwh's implication in the covenant inaugurating Joah's reign is mediated by the high priest, and Jehoiada has now become a party to the covenant, alongside the king and the people. ${ }^{60}$

58 See, e. g., Klein, 2 Chronicles, 319 and n. 26-27; Levin, Chronicles, 185.

59 Thus, e. g., Raymond B. Dillard, 2 Chronicles (WBC 15; Waco, Tx: Word Books, 1987), 178.

60 The other half of $2 \mathrm{Kgs}$ 11:17 mentions a second covenant, this time between Joash and the people, which is not mentioned in $2 \mathrm{Chr} 23: 16$. This omission is presumably due to the fact that the Chronicler had already mentioned a similar covenant in $2 \mathrm{Chr}$ 23:3 (thus, e. g., Japhet, Chronicles, 835). Klein, 2 Chronicles, 329, suggests that the Chronicler may have been dependent here on an alternate version of Kings, which did not contain this clause. 
(5) After reinstating Joash on the throne, Jehoiadah is said in 2 Chronicles 24:3 to have procured two wives "for him": וישא לו יהוידע נשים שתים. Although the wording of this clause is ambiguous, the third masculine singular suffix (לוידו) clearly refers to king Joash, who is the general subject of the immediate context (2 Chr 24:1-3). This verse is entirely an addition by the Chronicler. While it has not received much attention, the idea of the high priest being responsible for providing wives for the king is quite unique. Within the Western Asian context, it is reminiscent of the kind of vertical relationship uniting a suzerain and his vassal. ${ }^{61}$ This observation must however be balanced with the subsequent narrative in 2 Chronicles 24:4-14, which shows that Jehoiada remains de facto subordinated to the king (see, especially $2 \mathrm{Chr}$ 24:6). Nonetheless, the notice added by the Chronicler in 2 Chronicles 24:3 does index a position of power and influence for Jehoiada visà-vis of Joash. Furthermore, this notice calls into question the view that, in the Chronicler's perspective, Jehoiadah's political power would have been limited to the period preceding Joash's enthronement. ${ }^{62}$ On the contrary, 2 Chronicles 24:3 points to a more lasting influence for the high priest, extending into Joash's reign.

(6) Finally, according to the notice in 2 Chronicles 24:15-16, Jehoiada dies at the age of 130, which is more than Moses in Deut 34:7 (!), and also more than the maximal age set for humankind in Gen 6:3. What is more, Jehoiada is buried in the City of David, “together with the kings” of Judah (ויקברהו בעיר דויד עם המלכים), as a reward for the good he did during his life for "Israel, Yhwh and his temple". This notice is absolutely unique for a high priest in Chronicles (or in the Hebrew Bible for that matter), and appears to index again a royal or quasi-royal status for Jehoiada. ${ }^{63}$ In effect, it is the only notice in Chronicles reporting the death and burial of a figure who is not a king. ${ }^{64}$ Last but not least, the comparison with the notice for Joash in 2 Chronicles 24:25 provides an additional element of contextualization. Chronicles takes up Kings' notice in 2 Kings 12:22 according to which Joash was buried in the city of David, but corrects it by stating that he was not buried in the tombs of the kings (ולא קברהו בקברות המלכים). Chronicles' account of Joash and Jehoiada thus concludes with an exceptional situation, in which it is the high priest, instead of the king, who is buried in the royal tombs.

61 I am grateful to my colleague Ehud Ben Zvi (University of Alberta) for discussing this point with me.

62 Thus, e.g., Schweitzer, "High Priest,” 398.

63 Schweitzer, "High Priest," 398, also suggests that this may reflect "a retrojection of Second Temple practice by the Chronicler." While this is an intriguing possibility, it cannot be demonstrated and remains speculative, as Schweitzer himself acknowledges.

64 As finely noted by Klein, 2 Chronicles, 344. 
Taking this evidence together, it does not seem possible to avoid the conclusion that some sort of communal leadership, extending well beyond the boundaries of the sanctuary, is conferred to Jehoiada here. In effect, Jehoiada, who marries into the Davidic line, oversees and controls the whole procedure for Joash's establishment on the throne, provides wives for the king and is buried like a Judean king in the place of Joash himself, is somehow described in Chronicles as the closest equivalent to a king. However, this conclusion must be immediately qualified in two respects. Firstly, there is very little evidence for similar communal leadership in the case of other high priestly figures in Chronicles. Jehoiada may enjoy extended privileges and status, which bring him in close connection with royal figures, but he remains something of an exception in Chronicles. Secondly, Jehoiada is elevated in Chronicles only inasmuch as he remains loyal to the Davidic monarchy. In this respect, it is certainly significant that the plus in 2 Chronicles 23:3 reminding that kingship can only belong to the Davidic house is precisely placed in the mouth of Jehoiada, the high priest. In this way, the Chronicler's account also subtly recalls that high priests are normally not expected to take the place of kings.

\section{The missing high priest: the case of royal reforms in Chronicles}

In order to understand Chronicles' discourse on the high priest, we need to look not only at the passages where the high priest is mentioned but also at those passages where he would be expected but is actually absent. Contrary to some kings, like Amaziah (2 Chr 25), Ahaz (2 Chr 28) or Manasseh (2 Chr 33:1-20), the high priest is never explicitly criticized in Chronicles; but his absence in some contexts seems nonetheless significant. This is the case, in particular, in the context of royal reforms. The importance of royal reforms in Chronicles has been highlighted by several studies, especially in the case of the reigns of Hezekiah and Josiah at the end of the Chronicler's account of the Judean monarchy.$^{65}$ While this point has

65 See, especially, Hee-Sook Bae, Vereinte Suche nach JHWH. Die Hiskianische und Josianische Reform in der Chronik (BZAW 355; Berlin/New York: de Gruyter, 2005); for Josiah's reform in Chronicles compare also Louis C. Jonker, Reflections of King Josiah in Chronicles. Late Stages of the Josiah Reception in II Chr. 34f. (TSHB 1; Gütersloh: Gütersloher Verlagshaus, 2003). See further now Julia Rhyder, "The Reception of Ritual Laws in the Early Second Temple Period: The Evidence from Ezra-Nehemiah and Chronicles," in Text and Ritual in the Pentateuch: A Systematic and Comparative Approach, ed. Christophe Nihan and Julia Rhyder (Eisenbrauns: University Park, PA, 2021), 255-279, esp. 264-273, with additional references. 
not always been noted, it is striking to observe that the high priest plays a very limited role in both reforms.

The case of Chronicles' account of Hezekiah's reforms in 2 Chronicles 29-31 is especially instructive in this regard. While this account is complex, it presents nonetheless a logical structure. Following the notice introducing Hezekiah (2 Chr 29:1-2), the account begins by describing the purification of the temple (29:3-19), followed by sacrifices offered by Hezekiah and the officials of the city (29:20-30) as well as by the people (29:31-36). 2 Chronicles 30 continues with the celebration of Passover and Unleavened Bread in Jerusalem, which is also the occasion to eliminate from the city non-Yahwistic cult objects (30:14). In 2 Chronicles 31, finally, the whole land of Judah and Israel is purified (31:1), ${ }^{66}$ and various provisions are made by Hezekiah for collecting contributions to the priests and the Levites (31:2-21). It is not possible to provide here a comprehensive discussion of this fascinating yet complex account. In the limits of this essay, two general observations will suffice.

Firstly, it is striking to observe that the high priest plays no part in the reforms themselves, even at points where one would expect to see him mentioned. According to 2 Chronicles 29, the purification of the temple (see 29:3-19) and the reinstatement of the sacrificial cult (29:20-36) were decreed by Hezekiah. However, according to other passages in Chronicles (see above), maintaining the purity and sanctity of the sanctuary and warranting the continued offering of sacrifices are duties that typically belong to the high priest, ${ }^{67}$ who is nonetheless not mentioned in the context of 2 Chronicles 29. There are, however, good reasons for this absence of the high priest. In particular, Hezekiah's speech in 2 Chronicles 29:6-7 implies that the cult in Jerusalem has been completely discontinued, presumably as a consequence of Ahaz's impious actions as described immediately before, in 2 Chronicles $28 .{ }^{68}$ As various scholars have observed, the discontinuation of the

66 Thus, there is a clear concentric structure in the account of Hezekiah's reform, beginning with the purification of the temple (2 Chr 29:15-20) and extending gradually to the city (2 Chr 30:14) and finally the entire land (2 Chr 31:1). See further on this my discussion in Christophe Nihan, "Deuteronomic Alignment in Chronicles: Royal Reforms and the Elimination of Cultic Objects," in Writing, Rewriting and Overwriting in the Books of Deuteronomy and the Former Prophets, ed. Ido Koch, Thomas Römer and Omer Sergi (BEThL 304; Leuven et al.: Peeters, 2019), 309-336, here 319-324.

67 See, e. g., 2 Chr 26:16-21 for the first matter, and 1 Chr 16:39-40 for the second.

68 This is suggested, in particular, by the fact that the description of the discontinuation of the cult in $2 \mathrm{Chr}$ 29:7 begins with a reference to the doors of the temple having been shut, which corresponds to the action ascribed to Ahaz in $2 \mathrm{Chr} 28: 24-25$. For the view that the discontinuation of the cult described in Hezekiah's speech in 29:6-7 goes back to Ahaz, see, e.g., Williamson, Chronicles, 353; further Klein, 2 Chronicles, 416. 
cult is a reversal of "the situation initiated by Solomon (cf. 2:4 and 4:7) and reaffirmed by Abijah (13:11)". ${ }^{69}$ This reversal, in turn, justifies for the Chronicler the representation of Hezekiah as a new Solomon. ${ }^{70}$ Just like Zadok takes virtually no part in the initial organization of the cult under David and Solomon, ${ }^{71}$ there is apparently no need for the high priest alongside the king in Chronicles' account of Hezekiah's reestablishment of the cult. This conclusion is consistent with the fact that Azariah is effectively mentioned only after the cult has been reinstated and reorganized, in 2 Chronicles 31:10. As discussed above, this notice acknowledges the role of the high priest in the management of the temple's resources, and the account continues in 31:13 by showing Hezekiah and Azariah being jointly involved in the supervision of the storing of the contributions brought to the temple by the Israelites (cf. 31:4-7).

Secondly, while the high priest plays no role in the royal reform itself, it has often been observed that this reform provides an opportunity to highlight the role of the Levites. According to 2 Chronicles 29:4, Hezekiah gathered "the priests and the Levites", the subsequent speech placed in the king's mouth is exclusively addressed to "the Levites" (הלוים). It is very likely that הלוים is used here as a generic term, including all the members of the tribe of Levi, and not just the Levites, as various scholars have surmised. ${ }^{72}$ Even so, however, this usage of הלוים is significant. By recalling that priests and Levites share a common ancestor (Levi), it tends to provisionally bracket the differences between these two groups, suggesting that, at least in the context of Hezekiah's reform, Levites enjoy similar if not identical status as priests. This trend is continued in 29:12-14, which provides the genealogy of seven Levitical families (with the mention of two members for each family), ${ }^{73}$ whereas nothing is said about the genealogy of the priests involved in the reform (who are merely mentioned as "the priests"). Later

69 Williamson, Chronicles, 353.

70 On this topic, see, especially, Mark A. Throntveit, "The Relationship of Hezekiah to David and Solomon in the Books of Chronicles," in: The Chronicler as Theologian: Essays in Honor of Ralph W. Klein, ed. M. Patrick Graham, Steven L. McKenzie and Gary N. Knoppers, (JSOT.S 371; London/ New York: T \& T Clark, 2003), 105-121.

71 The only partial exception is $1 \mathrm{Chr}$ 24:3-6, where Zadok is associated, together with Ahimelek, to the division of Aaron's descendants by David. Note, however, that $1 \mathrm{Chr} 24$ is generally considered to be a later addition within Chronicles.

72 See, e. g., Japhet, Chronicles, 917; Klein, 2 Chronicles, 415. Contra Antje Labahn, "Antitheocratic Tendencies in Chronicles," in: Yahwism After the Exile. Perspectives on Israelite Religion in the Persian Era. Papers Read at the First Meeting of the European Association for Biblical Studies, Utrecht, 6-9 August 2000, ed. Rainer Albertz and Bob Becking (STAR 5; Assen: Royal Van Gorcum, 2003), 115-135, here 118, who considers that הלוים refers here to the Levites alone.

73 For a detailed discussion of these families, see, e. g., Klein, 2 Chronicles, 417-418. 
in the account, Levites are described as being involved in sacrificial roles which are normally reserved to the priests. According to 2 Chronicles 29:34, the Levites were allowed to assist the priests in skinning he animals brought by the community to be sacrificed as burnt offerings (see 29:31-36), because the priests were too few. In order to legitimize what is apparently a ritual innovation, Chronicles adds a further rationale, stating that "the Levites were more upright of heart in sanctifying themselves than the priests” (כי הלוים ישרי לבב להתקדש מהכהנים). ${ }^{74}$ Later, in 30:16, Levites are also presented as handing the blood of the Passover sacrifices to the priests, ${ }^{75}$ and in 30:17 they slaughter the Passover lambs on behalf of the participants to the festival who could not purify themselves. ${ }^{76}$ The elevation of the Levites in this account culminates in 30:22, when the contribution of the Levites to the festival is acknowledged by Hezekiah himself, who "speaks to the heart of the Levites” (וידבר יחזקיהו על לב כל הלוים), ${ }^{77}$ an expression apparently meaning that he speaks to them favorably, or encouragingly. ${ }^{78}$ Overall, there is a clear tendency throughout the account of the purification of the temple, the reestablishment of the cult ( 2 Chr 29) and the celebration of Passover in Jerusalem (2 Chr 30) to highlight the role of the Levites in the success of these ceremonies, and especially their readiness to assist the king in his cultic and religious reform.

A very similar point can be made in the case of Josiah's cultic reform and celebration of the Passover ( $2 \mathrm{Chr} 35)$. The high priest Hilkiah is mentioned in the account of the repairs of the temple ( $2 \mathrm{Chr} 34: 9$, cf. $2 \mathrm{Kgs} \mathrm{22:4)}$ and the finding of the "book of the law" (2 Chr 34:14-15, cf. 2 Kgs 22:7-8), as already in Kings. ${ }^{79}$ But

74 On this verse and its implications, see, especially, the detailed discussion by Bae, Vereinte Suche, $125-128$.

75 As observed by Japhet, Chronicles, 949-950, the Chronicler introduces two innovations here: (a) the idea that the blood of the Passover sacrifice must be sprinkled against the altar, like the blood of burnt and well-being offerings in P (Lev 1:5, 11; 3:2, 8, 13); (b) the notion that the Levites carry that blood from the place where the animal has been slaughtered to the priests. The statement in v. 16a that the priests and the Levites "stood in their posts according to their custom, according to the Torah of Moses, the man of God" has been much discussed. Presumably, this statement does not point to a specific commandment but, rather, to the general conformity of this procedure with the instructions of the Mosaic Law.

76 For a discussion of this passage, see Bae, Vereinte Suche, 130-133.

77 Contrary to 29:5, I see no reason here to interpret הלוים inclusively; the focus on the Levites is in keeping with the insistence on the readiness of the Levites throughout $2 \mathrm{Chr} 29-30$ (see, especially, 29:34). Compare, e. g., Bae, Vereinte Suche, 131-132; Klein, 2 Chronicles, 439; pace Japhet, Chronicles, 954.

78 See Gen 50:21; Isa 40:2. Klein, 2 Chronicles, 439, renders this expression with "tenderly”. 79 See further $2 \mathrm{Chr} 34: 20-22$ (// 2 Kgs 22:12-14), where Hilkiah, the high priest, is mentioned among the men sent by Josiah to seek an oracle from the prophetess Huldah. 
contrary to what is the case in Kings (2 Kgs 23:4) he is no longer mentioned in the context of the account of the purification of the temple, which is described more briefly in 2 Chronicles 34:3-7. The high priest likewise plays no significant role in the celebration of Passover under Josiah (2 Chr 35). He is merely mentioned among other temple authorities (נגידי בית האלהים, "leaders of the house of the god”) who contribute to the sacrifices with a generous donation of animals (35:8), but no longer in the performance of the ceremony itself. Moreover, it is not even certain that the "Hilkiah" mentioned in this verse is the same person as the high priest with this name in 2 Chronicles $34 .^{80}$ By contrast, the Levites play a key role in the celebration of the festival described in 2 Chronicles 35, comparable to or even more important than in the case of Hezekiah's Passover in 2 Chronicles 30 . The role of Levites is already prepared in 35:3-6, where they receive detailed instructions from Josiah himself for the celebration of Passover. ${ }^{81}$ In the account of the celebration (35:10-16), they are described in a variety of ritual roles. As in 2 Chronicles 30:17, they slaughter the Passover lamb and skin the animals (35:11; cf. already $29: 34)^{82}$; they set apart the fat portions of the animals to be burnt by the priests (35:12); they cook the animals and bring them to the people gathered in Jerusalem (35:13); and last but not least they prepare portions for the priests, themselves (35:14), and even other Levites such as the singers and the gatekeepers who are on duty and cannot leave their posts (35:15). In short, except for those ritual actions involving contact with the altar (namely, sprinkling the blood against the altar, and burning the fat portions of the sacrifices), which are reserved to the priests, ${ }^{83}$ Levites are responsible for all the remainder of the ceremony. Their importance in the success of the ceremony is further emphasized by the notice in 35:9, which specifies that the "chiefs of the Levites" contributed animals to the Passover sacrifices with a donation of 5,000 sheep and 700 hundred bulls, which is roughly the double of the donation made by the leaders of the priests according to $35: 8(2,600$ sheep and 300 hundred bulls).

All in all, while we must be cautious not to infer too much from omissions in Chronicles, some significant patterns can nevertheless be identified as regards the general omission of the high priest in the context of royal reforms. Both Hezekiah and Josiah are presented as being responsible for the reestablishment of the cult in Jerusalem, after it was discontinued by their predecessor on the throne (Ahaz

80 See, e. g., Klein, 2 Chronicles, 521; Levin, Chronicles, 421 n. 133.

81 On this section and its function in the account of $2 \mathrm{Chr} 35$, see the detailed analysis by Bae, Vereinte Suche, 139-144. Compare also Rhyder, “Reception”, 270-271.

82 As Bae, Vereinte Suche, 145-146, aptly observes, what was still an exceptional measure in $2 \mathrm{Chr} 30$ is now presented as a regular privilege for the Levites.

83 See 2 Chr 35:11 and 12 respectively for these two ritual actions. 
in $2 \mathrm{Chr}$ 28; Manasseh in $2 \mathrm{Chr}$ 33). This situation provides the opportunity to compare them with David and Solomon, the founders of the royal dynasty and of the cult in Jerusalem, two domains which are deeply intertwined in Chronicles. By contrast, the high priest never plays any role in these reforms, and is exclusively mentioned in the context of issues related to the administration of the temple. ${ }^{84}$ This suggests that in Chronicles the foundation and renovation of the cult remains essentially a royal initiative, whereas the function of the high priest is much more associated with the management of the temple. Furthermore, while royal reforms in Chronicles mobilize various ritual agents, the accounts in 2 Chronicles 29-30 and 2 Chronicles 35 show a clear preference for the Levites, who are presented as enjoying a special relationship to the king in the context of those reforms. ${ }^{85}$ Levites are thus clearly positioned in Chronicles as privileged ritual agents in connection with the purification and refoundation of the cult, and this privileged position is explicitly affirmed in some passages which highlight the Levites' outstanding zeal during the royal reforms, such as 2 Chronicles 29:34.

Overall, while the accounts of Hezekiah's and Josiah's reform in Chronicles make repeated reference to the Mosaic Law and are partly consistent with the prescriptions laid in the priestly portions of the Pentateuch, the conception of the cult that emerges from these accounts is substantially distinct from that of the priestly texts. In the priestly texts, the high priest is basically at the head of the cult and is personally responsible for maintaining the sanctity and the purity of the sanctuary. This conception somehow culminates in the grand ritual of Leviticus 16 , which can only be performed by the high priest, and which warrants in principle that the temple (16:14-19) and the community (16:20-22) are regularly purified and therefore can never become irremediably defiled. ${ }^{86}$ In this system, Levitical families have a role to play in the preservation of the sanctuary's integrity, at least according to the Book of Numbers ${ }^{87}$. Yet they remain clearly subordinated to the high priest and his family, and can only undertake more menial tasks. The accounts of cultic reforms in Chronicles point therefore to a different balance of power between the priestly and Levitical families as is the case in Numbers. In Chronicles' conception the ritual monopoly of the Aaronite priests is recognized in principle, but it is no longer enough to warrant the purity and sanctity of the temple and its cult.

84 See 2 Chr 29:10, 13 (Azariah); 34:14-15, and perhaps 35:8 (Hilikiah).

85 This is apparent, in particular, from the royal speeches to the Levites in $2 \mathrm{Chr} 30: 22$ and 35:3-6 (see above).

86 See on this my discussion in Nihan, Priestly Torah, 370-379.

87 See, especially, Num 3-4 and 8. 


\section{Conclusion: the high priest in Chronicles and in the priestly texts of the Pentateuch}

The previous discussion provides a basis to address the issue of the relationship between the description of the high priest in Chronicles and in the priestly texts of the Pentateuch. Specifically, four aspects relevant to the comparison between Chronicles and the priestly texts can be briefly highlighted here.

(1) Like the priestly texts, Chronicles consistently emphasizes the high priest's role in the sanctuary. In fact, except for Jehoiada in 2 Chronicles 22-24 (on which see below), all the other references to high priests in Chronicles exclusively focus on their role in connection to the sanctuary and its management. Chronicles' description of high priestly roles with regard to the sanctuary presents a number of connections with the priestly texts, but also some substantial discontinuities. To begin with, Chronicles posits a distinction between non-ritual and ritual matters in the management of the sanctuary. While the high priest de facto operates as the main administrator of the sanctuary, several texts indicate that the king, as the patron and financial sponsor of the temple, retains a substantial degree of control over this institution and can even intervene in its actual management, at least in specific circumstances (see, e. g., 2 Chr 31:11-13, and the discussion above $\S 2)$. This situation, however, does not confer any prerogatives to the king in ritual matters; the account of king Uzziah in 2 Chronicles 26 effectively establishes this point. Such distinction between non-ritual and ritual matters in the management of the temple is unknown to the priestly texts, which merely assume that the high priest and the main priestly families enjoy complete control over the sanctuary (compare, e.g., Num 18).

(2) With regard to ritual matters, specifically, Chronicles' description of high priestly roles is largely based on priestly materials, as one would expect, but these materials are reused both freely and selectively. In particular, high priestly ritual hegemony in Chronicles is expressed almost exclusively through reference to the performance of the daily sacrifices. Other key markers of the high priest's ritual hegemony in the priestly texts, such as the description of high priestly vestments (Exod 28), the ceremony of Yom Kippur (Lev 16) or specific laws pertaining to the high priest (Lev 21:10-15), are never mentioned in Chronicles. A further difference, which has not always been correctly noted, is that Chronicles tends to emphasize the collective nature of high priestly authority. Contrary to the priestly texts, Chronicles never ascribes the performance of daily rituals to the high priest alone, and always mentions other priests alongside him (see 1 Chr 6:34; 16:39-40). Moreover, texts like 2 Chronicles 13:11 or 26:18 even ascribe the performance of those same rituals to "the priests, sons of Aaron," rather than the high priest himself. 
(3) Both the priestly texts and Chronicles consider larger communal, extra-sanctuary roles for the high priest, but they do it in entirely distinct ways. In the priestly texts, such roles are almost exclusively developed in the book of Numbers. ${ }^{88}$ In particular, Numbers 17 recounts how Aaron performs a ritual inside the camp in order to ward off Yhwh's wrath, which is represented as a demonic force of sorts (cf. Num 17:6-15); Numbers 27 describes Eleazar casting lots for Joshua in order to determine when he must go to war (Num 27:21) ${ }^{89}$; and other passages describe him involved in the division of the land. ${ }^{90}$ None of these roles are mentioned in Chronicles for the high priest. Instead, Chronicles addresses this matter primarily through the figure of Jehoiada. As a matter of fact, Jehoiada is the only case where Chronicles effectively considers the possibility for a high priest to take extended communal roles. As argued above ( $\S 3)$, Chronicles' description of Jehoiada aligns him closely with a royal figure: he marries into the Davidic line, oversees and controls the whole procedure for Joash's establishment on the throne, provides wives for the king and is buried like a Judean king in the place of Joash himself. While not a king per se, Jehoiada is arguably construed in Chronicles as the closest equivalent to a king. However, there is no indication that the high priestly dynasty in Jerusalem could one day replace the Davidic dynasty. On the contrary, Jehoiada can take a quasi-royal role only because he is loyal to the Davidic dynasty, and pays lip service to the latter (2 Chr 23:3). Furthermore, there is likewise no evidence in Chronicles that other high priests could imitate Jehoiada or achieve equal status. Jehoiada in Chronicles is an exceptional high priest in exceptional circumstances, who steps up at a time when the Davidic monarchy is failing.

(4) Finally, a major difference between the descriptions of the high priest in the priestly texts and Chronicles concern his role in the maintenance of the sanctuary's purity and sanctity. In the priestly texts, the high priest is basically at the head of the cult and is personally responsible for maintaining the sanctity and the purity of the sanctuary. This conception somehow culminates in the grand ritual of Leviticus 16, which can only be performed by the high priest, and which warrants in principle that the temple (16:14-19) and the community (16:20-22) can never become irremediably defiled. In Chronicles, accounts about the defilement

88 The only (partial) exception would concern Aaron's roles in Exodus, before Exod 19 and Israel's arrival at Mount Sinai.

89 On this verse and its significance within the context of Num 27:12-23, see further my discussion in Christophe Nihan, "Joshua and Eleazar in Numbers 27," in: Bible and Politics. A Festschrift in Honor of Prof. Rev. Dr Olivier Artus on his 65th Birthday, ed. Sophie Ramond and Joseph Titus (Bangalore: ATC Publishers, 2019), 77-97.

90 Num 32:28; 34:17-18; further Josh 14:1-2; 17:4; 19:51; 21:1. 
of the sanctuary and its subsequent purification play an important part, but the high priest plays no role in those stories (see above, §4). In the accounts of Hezekiah (2 Chr 29-31) and Josiah (2 Chr 34-35), cultic reforms are expressly described as a royal initiative. While they involve various ritual agents, such as especially Levites and, to a lesser extent, priests and the rest of the community, the high priest is never mentioned among them: on the contrary, in the account of Hezekiah's reform he only comes into play after the cult has been reinstated (2 Chr 31:10). As a result, while Chronicles aligns with the priestly traditions in acknowledging the central role of the high priestly family in the management of the temple, a key difference is that in Chronicles this role is no longer construed as being sufficient to warrant the purity and sanctity of the temple and its cult. Instead, accounts of royal reforms provide the opportunity to present a new balance of power, which is substantially less vertical and more diverse than in the priestly texts. In this conception, high priestly management of the temple is not possible without the continued support of the king, and without the assistance of dedicated ritual agents such as the Levites.

Taken together, these points indicate that the various continuities in language and conception that can be observed between the priestly texts and Chronicles with regard to the high priest should not blind us to the substantial discontinuities that exist between these two corpuses. Chronicles' description is clearly based on the priestly texts, and uses them as a key reference in its description of the high priest. But it also regularly branches off in order to pursue its own agenda. In the end, the overall picture of the high priest that emerges is quite distinct from the priestly texts. On the one hand, Chronicles acknowledges some form of ritual hegemony to the high priest in ritual matters inside the sanctuary, and occasionally even confers him some larger communal responsibilities (Jehoiada in $2 \mathrm{Chr}$ 22-24). On the other hand, however, Chronicles also shows a clear concern to highlight the relational dimension of high priestly prerogatives within the sanctuary. Rituals inside the temple can only be performed with the assistance of other priests; temple management requires the cooperation between the high priest and the king; and the maintenance of the sanctuary's integrity likewise requires the intervention of other agents, like the Levites. The resulting picture is a description of high priestly leadership which is substantially less hegemonic, and more balanced, than in the priestly texts. 